\title{
MEASURING THE INTENSITY OF COMPETITION IN EXPORT MARKETS
}

\author{
Pinelopi K. Goldberg \\ Michael M. Knetter
}

Working Paper No. 5226

\section{NATIONAL BUREAU OF ECONOMIC RESEARCH 1050 Massachusetts Avenue \\ Cambridge, MA 02138}

August 1995

The authors acknowledge financial support from National Science Foundation Grant SBR9409339. In addition, Goldberg acknowledges support from the Hoover Institution and Knetter from the Rockefeller Fund at Dartmouth College. We thank seminar participants at NBER, Princeton, Dartmouth, Texas, Catholic University at Louvain-la-Neuve, and the IMF for helpful comments. Yuan Shen has provided valuable research assistance. Remaining errors are our own. This paper is part of NBER's research program in International Trade and Investment. Any opinions expressed are those of the authors and not those of the National Bureau of Economic Research.

(C) 1995 by Pinelopi K. Goldberg and Michael M. Knetter. All rights reserved. Short sections of text, not to exceed two paragraphs, may be quoted without explicit permission provided that full credit, including $(C)$ notice, is given to the source. 


\title{
MEASURING THE INTENSITY OF COMPETITION IN EXPORT MARKETS
}

\begin{abstract}
This paper develops an approach to measuring the intensity of competition in international markets. The method measures the degree of "outside" competition faced by exporters located in one source country from firms located outside the source country. We use the elasticity of price and quantity to exchange rate shocks, which shift the relative costs of producers from a particular source country, to calculate our measure of outside competition. The measures are estimated using panel data on exports of U.S. linerboard and German beer to a variety of destination markets. The destination-specific panel data allow comparisons of outside competition across destination markets.
\end{abstract}

Pinelopi K. Goldberg

Department of Economics

Princeton University

Princeton, NJ 08544

and NBER
Michael M. Knetter

Department of Economics

Dartmouth College

Hanover, NH 03755

and NBER 


\title{
Measuring the Intensity of Competition in Export Markets
}

\author{
Pinelopi K. Goldberg and Michael M. Knetter
}

Two important branches of empirical research in international trade and finance investigate the causes of exchange rate fluctuations under floating rate systems and the consequences of these fluctuations for the real economy. Recent empirical papers from the latter branch have examined the responses of many decision variables and performance measures to exchange rate fluctuations. The bulk of this research has been concerned with price adjustment, especially the measurement of exchange rate pass-through and pricing-tomarket. ${ }^{1}$ However, a substantial amount of research has investigated the related impact of exchange rate fluctuations on profits and profit margins, employment, investment, domestic prices, and the entry and exit of firms in international markets.

The empirical findings on pricing-to-market which show persistent exchange rate induced deviations from the law of one price imply that national markets for most manufactured goods should be viewed as segmented rather than integrated. It is likely that the degree of competition will vary across national markets within a particular industry according to trade and regulatory policies, market size, proximity to sources of supply, and other factors. A few recent papers link industry measures of pass-through with other industry characteristics, such as concentration ratios, capital/labor ratios, advertising expenditures, and market share, but the results to date are only suggestive of the nature and importance of imperfect competition. ${ }^{2}$ There are only a small number of papers that estimate markups of price over marginal cost in international markets. ${ }^{3}$ This paper

\footnotetext{
${ }^{1}$ Recent papers by Dornbusch (1987), Giovannini (1988), Feenstra (1989), Froot and Klemperer (1989), Hooper and Mann (1989), Kasa (1992), P. Goldberg (1995) and Harrison (1993) consider the issue of exchange rate pass-through, while Krugman (1987), Knetter $(1989,1993)$, Marston (1990), and Gagnon and Knetter (1993) investigate pricing-to-market. This recent research is closely related to earlier work on the law of one price by Isard (1977), Kravis and Lipsey (1977), and Richardson (1978), among others.

${ }^{2}$ See in particular the papers by Feenstra, Gagnon, and Knetter (1993), Lee (1993), and Yang (1993).

${ }^{3}$ Aw's (1993) study finds that Taiwanese footwear exporters behave competitively in the United States and Hong Kong, but are able to charge markups over cost on exports to Germany. Aw (1992) measures markups for two quality classes of Taiwanese footwear exports to the United States only. Harrison (1993)
} 
develops and applies a framework for estimating one measure of competition, the elasticity of residual demand faced by a group of producers, in segmented export markets. There are a number of reasons why estimation of the intensity of competition in export markets is important. New trade theory shows that the design of optimal trade policy requires knowledge about the nature of competition in international markets. In addition, it seems clear that only empirical research can resolve the debate about whether (possibly hidden) barriers to competition in Japan make that market less competitive and yet impenetrable to foreign producers (see Lawrence (1993) and Saxonhouse (1993)). Thus, the practical significance of much of the new trade theory and the resolution of debates about the degree of competition across markets and industries hinges on knowledge about behavior in international markets.

It is useful to characterize the competitive environment of firms competing in international markets as consisting of "outside competition" and "inside competition", respectively. Outside competition faced by exporters located in source country $\mathrm{X}$ in destination market $\mathrm{Y}$ refers to the competition from producers located outside source country $\mathrm{X}$. The intensity of outside competition faced by the exporters can be summarized by the elasticity of the residual demand they face collectively. An elastic schedule would reflect the presence of many close substitutes and intense competition from outside the group. Inside competition refers to the behavior of exporting firms within the source country vis-a-vis one another. If two export destinations have identical residual demand elasticities, but exporters are able to attain different degrees of collusion in their behavior in the two markets, then markups may differ in spite of the similar demand structure.

This paper will focus on estimating the degree of outside competition. Our approach essentially involves estimating reduced form price and quantity equations and using the partial derivatives with respect to exchange rate shocks in each equation to and Turkey. respectively. All of these papers require detailed data on costs in order to estimate markups. 
çalculate an elasticity of residual demand faced by exporters from the source country in each destination market. The strength of the approach lies in its non-parametric nature. Profit maximization is the only critical maintained hypothesis. Because no assumptions about functional forms of demand or cost are imposed, the results are not an artifact of the parameterization of the model. We argue that variation across export destination markets in residual demand is more likely a consequence of differences in the availability of alternative supply than differences in the elasticity of market demand. The validity of this argument will obviously depend on the particular markets and products under consideration. While residual demand elasticities can be calculated from reduced form equations on prices and quantities, conduct parameters or markups cannot be determined without additional information about marginal costs. The distinguishing characteristic of our approach is that it uses widely available 7-digit industry data to estimate the export price and quantity response to exchange rate changes using a cross-section of destination markets over time. The presence of multiple destinations allows us to control for the effects of changes in marginal cost on prices and quantities using time effects, as in Knetter (1989). ${ }^{4}$

This paper is organized as follows. Section I reviews the previous research on price adjustment and competition in international markets. In Section II we present the theoretical framework for measuring outside competition. Section III discusses the data used in our analysis. Section IV describes the estimation and results for U.S. exports of kraft linerboard paper and German exports of beer. We have focused on these two industries because there has been relatively little change in trade policies or foreign investment in either of them over the sample period and destination markets we consider. 5 The paper concludes with a brief summary of our results and suggestions for future work.

\footnotetext{
${ }^{4}$ In keeping with other recent empirical work in industrial organization, we forego the use of published accounting data to measure costs and markups directly since much research suggests that such data provide unreliable measures of the corresponding economic concepts (see Stigler and Kindahl (1971)).

${ }^{5}$ In an earlier manuscript we considered German auto exports, but German exports to North America were in large part replaced by local production due to the construction of a Volkswagen plant in Ohio in 1978. This regime shift was difficult to capture with simple dummy variables as the plant seemed to increase capacity initially and then decline sharply later in the sample. Our method is more powerful when sources
} 


\section{Previous Research}

Of the various lines of research on the impact of exchange rate fluctuations, the pricing studies are most closely connected to the issue of market structure. Theories of incomplete pass-through or pricing-to-market (PTM) typically rely on segmented markets and either imperfect competition or a dynamic adjustment process to explain departures from the predictions of simple competitive models. ${ }^{6}$ Empirical work has established evidence that is consistent with each of these models, but the inability to test specific models prevents us from drawing sharp conclusions about market structure or competition.

The empirical literatures on both pass-through and PTM reach the conclusion that exchange rate changes lead to markup adjustment in most industries. ${ }^{7}$ The existence of exchange-rate induced destination-specific variation in markups implies that price cannot equal marginal cost on shipments to all destinations. The finding of price discrimination in the PTM literature allows rejection of the null hypothesis of integrated world markets. ${ }^{8}$ Beyond this inference, it is difficult to draw firm conclusions about imperfect competition from price adjustment alone.

First, it is well established that the adjustment of markups to cost shocks for a firm is determined by the convexity of the demand schedule the firm faces. Convexity is not directly related to the level of demand elasticity faced by the firm, but rather to how elasticity changes along the demand schedule. Consequently, there is no direct link

of variation such as this are minimized. The role of foreign investment is interesting in itself, but something we plan to address in further work.

${ }^{6}$ See Krugman (1987) for a discussion of the various modeling approaches.

${ }^{7}$ U.S. export industries seem to be a notable exception to this tendency, although Knetter (1993) presents evidence that this may be a result of industry selection, while Lawrence and Rangan (1994) argue that it is a result of the predominance of transactions between multinational operations found in U.S. export data. ${ }^{8}$ Much of the pass-through literature cannot reject even this null hypothesis, since most pass-through research looks at single bilateral or multilateral price series. Thus, the markup changes that are associated with exchange rate changes are not necessarily destination-specific. Rather they may represent changes in the world price of the good. 
between pass-through or pricing-to-market and the markup of price over cost, which is a standard measure of the degree of market power or imperfect competition. Furthermore, market segmentation may result from protectionist trade policies rather than actions by firms to prevent arbitrage. If a firm faces a binding quantitative restriction in a foreign market, then the local currency price that clears the market will be invariant with respect to exchange rate changes. In this case, the price measured in units of the exporter's currency will necessarily adjust to offset the exchange rate change and maintain the local currency price in the foreign market. Harrison (1993) concludes, for example, that incomplete passthrough in the market for steel in the United States can be explained by restrictive trade policies enforced by the U.S. government. While this is unlikely to be the cause of incomplete pass-through and PTM in every industry, Harrison's work underscores the danger in drawing conclusions about conduct or competitiveness without taking account of the potential role of trade restrictions in affecting firms' behavior.

The inability to draw inferences about conduct from PTM studies stems primarily from the fact that cross-industry studies have not paid much attention to the quantity adjustments associated with price changes. ${ }^{9}$ Further insights into market structure or conduct require data on revenues or quantities in addition to prices. The next section describes how it is possible to use the response of prices and quantities to exchange rate changes to determine the intensity of competition across export destinations and construct relative measures of conduct or competition using non-parametric methods.

\section{Theoretical Framework}

In most industries firms face competition from other firms located within the same source country as well as from firms located outside the source country. In principle, there

\footnotetext{
${ }^{9}$ Aw's $(1992,1993)$ work is exceptional in this regard, however, as noted earlier, her framework required detailed data on costs for Taiwanese footwear exporters. Our approach is applicable in settings where cost data are unavailable.
} 
may exist a very large number of own- and cross-price elasticities of demand in such a market. In order to make the problem of estimating competition or conduct tractable, analysts typically make simplifying assumptions about how the market is defined. In some cases, it may be reasonable to treat all goods in the industry as homogeneous. In other cases, the Armington assumption may be more appropriate-i.e., products within an industry are differentiated according to country of production. In that case, goods produced inside the source country are perfect substitutes with each other but imperfect substitutes with the same product produced in another country (e.g., beers from Germany and the United States may be imperfect substitutes, but U.S. beers are perfectly substitutable with each other). In the following we assume that exports from within the source country are perfect substitutes for each other, but goods produced outside the source country can be either perfect or imperfect substitutes. ${ }^{10}$

Consider a group of exporters selling in a particular foreign market. Let $p^{e x}$ be the price of the export good, $Q^{e x}$ be the total quantity of exports from the source country to this destination market, $p^{1}, \ldots, p^{n}$ be the prices of $n$ competing products produced in other countries, and $Z$ be a vector of demand shifters in the destination market. Demand functions for the exporters and the outside competitors may be written as follows:

$$
\begin{aligned}
& p^{e x}=D^{e x}\left(Q^{e x}, p^{1}, \ldots p^{n}, Z\right) \\
& p^{k}=D^{k}\left(Q^{k}, p^{j}, p^{e x}, Z\right) \text { where } j=1, \ldots, n \text { and } j \neq k
\end{aligned}
$$

In any single destination market, the first-order condition for the profit maximizing exporter $i$ is given by:

\footnotetext{
${ }^{10}$ Thus, this framework need not impose the Armington assumption, since products produced in different countries may be perfect substitutes.
} 
$p^{e x}=e \cdot M C_{i}^{e x}-q_{i}^{e x} \cdot D_{1}^{e x}\left(1+\sum_{j \neq i} \frac{\partial q_{j}^{e x}}{\partial q_{i}^{e x}}\right)\left(1+\sum_{k} \frac{\partial D^{e x}}{\partial p^{k}} \cdot \frac{\partial D^{k}}{\partial p^{e x}}\right)$

where $e$ is the exchange rate (source country currency per unit of destination market currency) and $D_{l}$ denotes the partial derivative of the demand function with respect to its first argument. The first term in braces, which we denote by $\theta_{i}$, captures the competitive behavior among exporters within the source country and is thus referred to as "inside competition." The second term in braces, which we denote by $\varphi$, captures the competitive interaction between source country firms and foreign producers and is referred to as "outside competition." Using this notation, the first-order condition is:

(3) $p^{e x}=e \cdot M C_{i}^{e x}-q_{i}^{e x} \cdot D_{1}^{e x} \cdot \varphi \cdot \theta_{i}$

It is important to note that despite the similarity of $\theta$ and $\varphi$ to conjectural variations parameters, the specification of the first order condition does not imply that firms actually play a conjectural variations game with conjecture $r_{i}=\theta_{1}-1$; instead this parameter should be interpreted as a measure of the average collusiveness of observed behavior that is consistent with a variety of structural models. Thus, $\theta$ and $\varphi$ measure how firms actually behave as a result of their expectations about how their competitors' outputs will respond to their own, and not the expectations themselves. Similarly for competitors we have firstorder conditions of the form:

(4) $p^{k}=M C^{k}-Q^{k} \cdot D_{1}^{k} \cdot \vartheta^{k}, \mathrm{k}=1, \ldots, \mathrm{n}$

Equation (3) reveals how the exporters marginal revenue depends on the interactions among firms in the exporting country as well as the interactions between the exporters and foreign competitors. 
Our concern is with the estimation of the slope (or elasticity) of the residual demand schedule facing a group of exporters, given by $D_{1}^{\text {res,ex }}=D_{1}^{e x} \cdot \varphi$, across different export destinations. Estimation of (3) requires firm-level data, but unfortunately, in most industries only market data are publicly available. Rather than using implausible aggregation assumptions (such as symmetry of firms), we prefer to interpret parameters as industry "averages," where averages are share-weighted means for all firms in the source country. ${ }^{11}$

The residual demand schedule faced by a firm or group of firms summarizes the constraints placed on behavior by other (outside) firms in the market. Properties of the residual demand schedule, such as elasticity, will depend on properties of the market demand schedule, $D^{e x}$, and the supply schedules (supply relation) of other firms in the market, summarized by $\varphi$. If market demand schedules are assumed to have the same elasticities in different destinations, which corresponds to the standard assumption in international economics that preferences do not vary across countries, then differences in residual demand elasticities across destinations reflect differences in the elasticity of alternative supply across destinations-i.e., differences in outside competition. A brief discussion of the residual demand framework, aided by Figure 1, will clarify the model and interpretation.

11 In particular, multiplying (3) by the market share, $s_{\mathbf{i}}$, of each of the export firms and summing across firms yields the condition: $\sum_{i} s_{i} \cdot p^{e x}=\sum_{i} s_{i} \cdot e M C_{i}^{e x}-\sum_{i} s_{i} \cdot q_{i}^{e x} \cdot D_{1}^{e x} \cdot \varphi \cdot \theta_{i}$. After some manipulation and taking into account $\sum_{i} s_{i}=1$ and $q_{i}^{e x}=s_{i} \cdot Q^{e x}$, we obtain a transformed version of (3) that can be estimated with market level data: $p^{e x}=e \cdot M C^{e x}-Q^{e x} \cdot D_{1}^{e x} \cdot \varphi \cdot \theta$, where $M C^{e x}=\sum_{i} s_{i} \cdot M C_{i}^{e x}$, and $\theta=\sum_{i} s_{i}^{2} \cdot \theta_{i}$. 

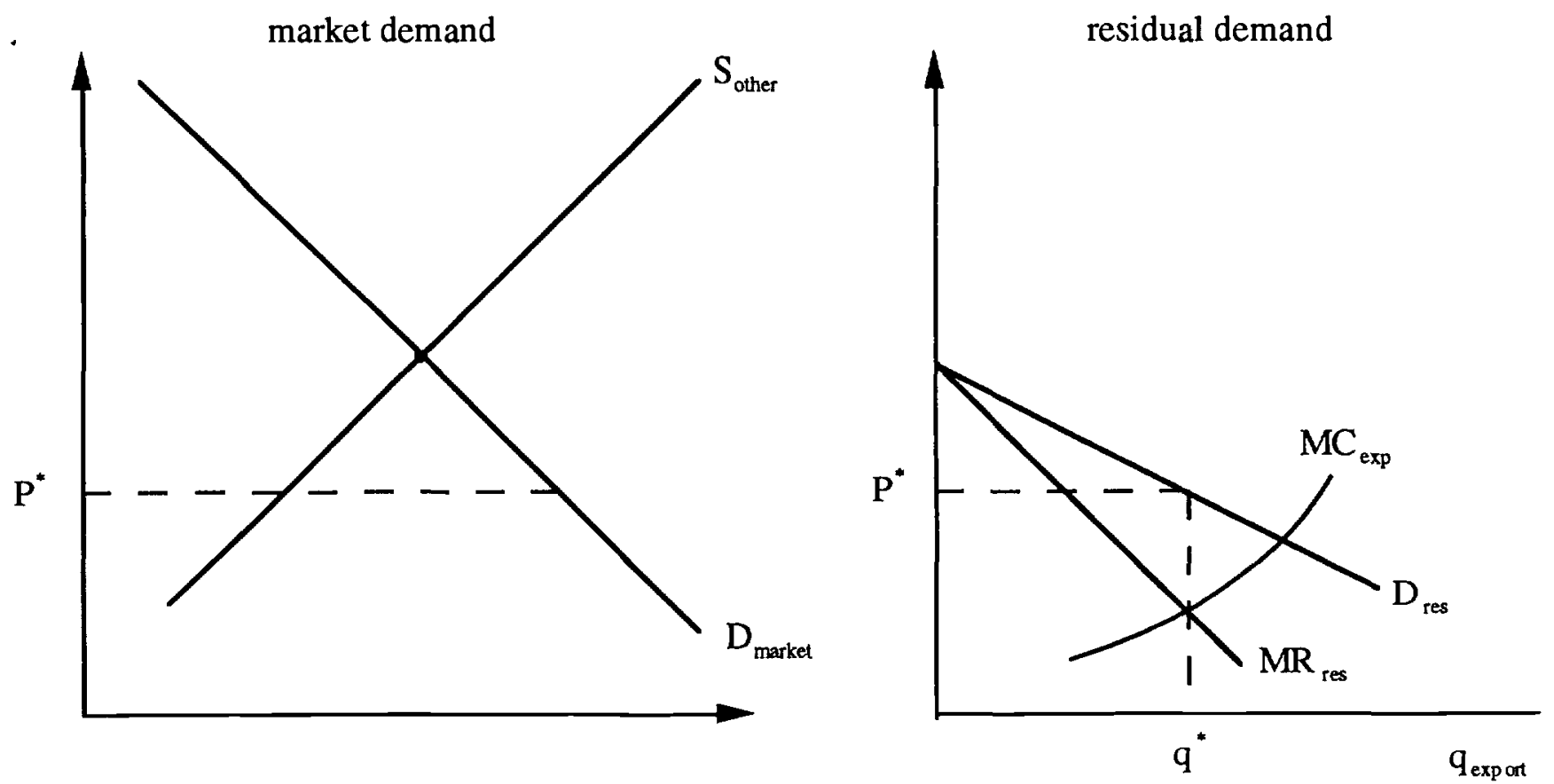

FIGURE 1. The right panel is the residual demand schedule for the exporter's product, which is derived from the market demand and other firms' supply in the left panel.

The left panel of the figure depicts the market demand curve for a homogeneous product in the destination country, as well as the supply curve for all competitors outside the export source country (for which no data are available). The right panel plots the residual demand curve facing firms from the source country along with their supply schedule (in this case assumed to be given by the marginal cost curve). Our approach and data do not allow statements about the entities in the left panel; we are, however, able to estimate the elasticity of the residual demand curve. A condition required to estimate the residual demand elasticity is that there be some shock that shifts the costs of production of source country firms relative to other suppliers in the market. Exchange rate fluctuations do exactly that, by rotating the source country firms' supply curve. As is evident from the figure, the elasticity of residual demand depends on both the elasticity of the market demand and the elasticity of the "outside firms"' supply curve. The latter constitutes the "outside competition" faced by exporters from the source country in this particular 
destination market. A sufficiently rich data set could disentangle the relative contributions of market demand and competing supply on residual demand. ${ }^{12}$ For now, we are content to simply assume that the market demand characteristics for some products are likely to be similar across destinations, so that variation across destinations in competing supply is responsible for variation in residual demand elasticities. Although Figure 1 refers to the homogeneous products case, the extension to heterogeneous products is straightforward.

Estimation of the residual demand schedule involves the following conceptual steps. ${ }^{13}$ First, we solve the equation system defined by (2) and (4) for the prices and quantities of the competitors' products. In general, the marginal cost for competitor $k$, $M C^{k}$, will be a function of the quantity produced, $Q^{k}$, and a vector of cost shifters, $W^{k}$, so that the first-order condition (4) can be written as follows:

$$
p^{k}=M C^{k}\left(Q^{k}, W^{k}\right)-Q^{k} D_{1}^{k}\left(Q^{k}, p^{j}, p^{e x}, Z\right) \vartheta^{k}
$$

After solving the system of $2 n$ equations defined by (2) and (4), we obtain the prices of the competitors' products as functions of the cost and demand shifters for the $n$ products, $W^{n}$ and $Z$ respectively, and the quantity (or price) of the export good, $Q^{e x}$ :

(5) $p^{k}=p^{k^{*}}\left(Q^{e x}, W^{n}, Z, \vartheta^{n}\right), \mathrm{k}=1, \ldots, \mathrm{n}$

The dependency of $p^{k}$ on $Q^{e x}$ arises because only the competitors' products $1, \ldots, n$ have been solved out. Next we substitute the $n$ expressions defined by (5) into (1), to eliminate the prices of competing products from (1):

$$
p^{e x}=D^{e x}\left(Q^{e x}, p^{1^{*}}, \ldots, p^{n^{*}}, Z\right)=D^{r e s, e x}\left(Q^{e x}, W^{n}, Z, \vartheta^{n}\right)
$$

\footnotetext{
12 We intend to assemble such a data set in future work for one or more industries.

13 Bresnahan (1989) provides a detailed discussion of the estimation of residual demand facing a single firm.
} 
The slope of $D^{r e s, e x}$ corresponds to $D_{1}^{e x} \bullet \varphi$ (henceforth $D_{1}^{r e s, e x}$ ). It gives us the slope of the demand curve facing the export firms, taking into account the competitive reaction of all other firms in the market. An example may illustrate the usefulness of the residual demand elasticity as a measure of outside competition. Suppose that the $k$ firms are price takers $\left(p^{k}=M C^{k}\right.$ ). Then $\varphi=1$, and if the export firms have no market power then our estimate of the slope of $D^{r e s, e x}$ should be zero. The prices of all other products determine $p^{e x}$.

To estimate the residual demand elasticity, $D_{1}^{r e s, e x}$, in each market we exploit the exchange rate variation and estimate reduced-form equations for prices and quantities of the following general form:

$$
\begin{aligned}
& \ln p_{m t}^{* e x}=\lambda_{m}^{1}+\alpha_{m}^{1} \ln z_{m t}+\varphi_{m}^{1} \ln w_{m t}+\beta_{m} \ln e_{m t}+\gamma_{m}\left(\ln e_{m t}\right)^{2}+\varepsilon_{m t}^{1} \\
& \ln Q_{m t}^{* e x}=\lambda_{m}^{2}+\alpha_{m}^{2} \ln z_{m t}+\varphi_{m}^{2} \ln w_{m t}+\delta_{m} \ln e_{m t}+\zeta_{m}\left(\ln e_{m t}\right)^{2}+\varepsilon_{m t}^{2}
\end{aligned}
$$

where $\varepsilon_{m t}^{1}$ and $\varepsilon_{m t}^{2}$ are iid error terms, the other Greek letters denote parameters to be estimated and the subscript $m$ indexes a specific market, defined as a destination-product pair. The above specification implies that separate regressions will be run for each country and each product; alternatively, one can pool the data on exports of a particular product to various destinations. The logarithmic specification is somewhat arbitrary, but has the advantage that the parameters $\beta_{\mathrm{m}}, \gamma_{\mathrm{m}}, \delta_{\mathrm{m}}$, and $\zeta_{\mathrm{m}}$ can be used to calculate the elasticities of the reduced form price and quantity equations with respect to the exchange rate and ultimately the elasticity of the residual demand schedule. ${ }^{14}$

To illustrate what is included in the demand and cost shifters, consider the case of U.S. linerboard paper. The cost shifters, $w$, should include measures of wages, prices of

\footnotetext{
${ }^{14}$ In estimation we consider alternative specifications of the reduced form, but choose to defer discussion of specification issues until the estimation section.
} 
raw materials, such as pulp and pulp products, and energy prices. An alternative approach for the case of multiple export destinations is to include a full set of time effects in a panel regression which pools the pricing equations for all of the destination markets. The time effects then capture the common movement in export prices to all markets which might be attributed primarily to cost changes. ${ }^{15}$ If markets are segmented, then demand shifters are destination-specific while cost shifters are not-i.e., cost changes will affect revenues in all markets.

The demand shifters, $z$, will typically consist of various combinations of a time trend, real income, and the price level for each destination market. The export demand shifters must also in principle account for factors such as foreign direct investment and trade restrictions and their resulting impact on trade volumes and prices. As noted earlier, we have selected industries in which there is little variation in tariffs over our sample period and no new foreign direct investment to our knowledge.

\section{Data}

The data used in this study are the annual value and quantity of exports to various destination countries for selected 7-digit industries. The data cover two export industriesone each from the United States and Germany-over the floating exchange rate period. ${ }^{16}$ We focus our study on two industries we know fairly well in order to minimize the possibility of omitting important variables in estimation (e.g., major changes in trade barriers in a destination market) and the consequent problems that would arise in interpretation. The data are taken from customs declaration forms at the port of export. The values are in units of the exporter's currency net of transportation, insurance, and

\footnotetext{
${ }^{15}$ Knetter $(1989,1995)$ discusses the conditions under which time effects will be a good control for cost changes.

16 Our data series currently end in 1987 . We are attempting to extend our data through 1991 , but the change to 10-digit industry definitions after 1988 has made it difficult to construct consistent series.
} 
tariffs. The values and quantities together can be used to construct unit value measures of prices. Hence, we have observations on total revenue, price, and quantity for each export destination for a 7-digit export industry.

For each source country-industry pair, exports to a number of relatively large (in terms of sales) export destinations are collected. Eligible destination markets are those that have currencies that fluctuate in value against the exporter's currency, since exchange rates are the critical variable which rotates the industry supply schedule in the source country. The aim in choosing large destinations is to improve the accuracy of the unit values as a measure of price and to avoid cases in which price is not observed because of a lack of shipments. 17

Industry selection was guided by several factors. Most important is the need to obtain information about trade policies and foreign investment in the destination markets. These policies and investment decisions may have big effects on industry equilibria. In the longer term, we will assemble the data on FDI and trade barriers by source and destination market for a limited set of industries. Our intermediate run solution is to avoid industries where we are aware of major changes in trade policies or shifts in the location of a substantial amount of production by the source country exporters. Thus, fairly mature and stable industries like German beer and U.S. paper seemed like a good starting point. ${ }^{18}$ The choice of annual frequency reflects primarily the need to economize on data collection effort.

${ }^{17}$ In some products it may be necessary to move to larger units of observation than countries. This need arises in part because firms sometimes ship to "base points" in a particular region before distributing goods to the ultimate buyers. For example, most U.S. cigarette shipments to Europe arrive first in Belgium before being sent on to their final destination and are thus counted as U.S. exports to Belgium. Serious problems arise in interpreting the behavior of quantities when base points are changed. Such problems may be avoided by working with regional data--such as North America, Continental Europe, the U.K., Japan, and Australia. We do not believe this is a problem with German beer and U.S. linerboard exports.

18 In an earlier version we also examined German auto exports, but we have dropped this industry from our work for now for two reasons. First, the differences in the composition of German auto exports across destinations is far too great for us to make any estimates of conduct, since differences in prices are likely to reflect different average product quality as opposed to different degrees of collusion. Second, Volkswagen built a plant in the United States in the late 70s, which caused a big change in export flows from Germany to the United States and Canada. The German beer industry is more satisfactory in both respects. 
The exchange rate series is based on the annual average nominal exchange rate published in International Financial Statistics. Wholesale price indices, used to measure destination-market inflation, and real GDP data (both used as demand shifters) are annual averages taken from International Financial Statistics. Tariff rates were obtained from sources at the International Trade Commission Library. Since they showed little change over time, but were not available for each year in our sample, we do not include them in estimation.

\section{Estimation and Results}

We consider behavior in two export industries-U.S. linerboard paper and German beer. We chose these industries for two main reasons. First, we are aware of little change in regulatory interference in trade in these products (e.g., tariff rates have been basically stable over the sample period and we are not aware of any quantitative restrictions imposed by the destination markets). Second, both product categories are relatively homogeneous, so that the assumption of equal marginal cost across export destinations seems reasonable. Hence, we are quite confident that price differences across markets that cannot be explained by differences in the residual demand elasticities reflect differences in competitive conduct rather than differences in the qualities sold in each market.

\section{1. German Exports of Beer}

Our data set contains information on German beer sales in five export destinations: Canada, France, Japan, the United Kingdom and the United States. The sample period is 1975-87. To our knowledge, German exporters did not face quantitative restrictions in any of these markets during the sample period, nor did tariff rates in these markets experience major changes. The reduced form price and quantity equations were estimated by Least 
Squares, after pooling data across markets and introducing common across equations time effects. Thus, the system of equations we estimate has the following form:

$$
\begin{aligned}
& \ln p_{m t}^{* e x}=\lambda_{m}^{1}+\alpha_{m}^{1} \ln z_{m t}+\tau^{1}+\beta_{m} \ln e_{m t}+\gamma_{m}\left(\ln e_{m t}\right)^{2}+\varepsilon_{m t}^{1} \\
& \ln Q_{m t}^{* e x}=\lambda_{m}^{2}+\alpha_{m}^{2} \ln z_{m t}+\tau^{2}+\delta_{m} \ln e_{m t}+\zeta_{m}\left(\ln e_{m t}\right)^{2}+\varepsilon_{m t}^{2}
\end{aligned}
$$

where $m$ indexes our five destinations, and $\tau_{1}$ and $\tau_{2}$ denote the time effects (common across destinations) in the two equations. The demand shifters consist of real income variables for each destination. The obvious cost shifters for competing products are the exchange rates of other beer exporting countries against the local destination currency; to the extent that German exporters face competition from different countries in each market, the vector of other exporters' cost shifters is destination specific, and the parameters associated with it are identified. In the case of beer, however, the main competition to German exporters (besides competition from local suppliers in the destination market) comes from the same exporting country, the Netherlands, with Heineken and Amstel. Any cost shifter that appears in every destination market cannot be separately identified in the presence of the time effects in the model. ${ }^{19}$ Intuitively, our framework provides no additional identification power if the source country firms compete with exactly the same competitors in every foreign market, since the rotation of relative supply curves will be the same in all markets in each period. In practice, this is almost never the case. ${ }^{20} \mathrm{We}$ are still able to identify the source/destination country exchange rate parameters, and thus calculate the residual demand elasticities. This conceptual issue only emphasizes the fact that the

\footnotetext{
19 Arbitrage implies that once the source/destination and the competitor/destination exchange rates are known, the source/competitor exchange rate is known too. Thus, if we put both the source/destination and competitor/destination log-exchange rates in the estimation, the sum of the two is equal to the source/competitor log-exchange rate, which is not destination specific.

${ }^{20}$ Even where the identity of suppliers is the same in every market, their relative importance is likely to differ across destinations (usually firms do relatively better in terms of market share in their home market, for example).
} 
time effects do not have a structural interpretation, as they control for a number of different factors that affect prices (and quantities) in all destination markets.

The results from the preferred specification, among several alternatives which were considered, are reported in Table 1 , columns 1 and $2 .{ }^{21}$ In general, the parameters have the expected signs and are precisely estimated. In the pricing equations we are interested in the coefficients on the nominal exchange rate, $\beta$ and $\gamma$, that are used to calculate the response of local currency prices to exchange rates, net of any changes in cost that are associated with exchange rates. ${ }^{22}$ In all markets but Japan, local currency prices change by about $50 \%$ of any change in the local currency exchange rate with the Mark; in Japan local currency prices change in proportion to the exchange rate, i.e., pass-through is complete. As we emphasized in the introductory section, however, pass-through coefficients do not provide any information on the degree of competition in the destination markets. We therefore turn to the residual demand elasticities reported in column 3 of Table 1.

We interpret the residual demand elasticities as measuring the outside competition German beer exporters face in each destination, where a higher (in absolute value) elasticity denotes "tougher" competition. ${ }^{23}$ Our results imply that German exporters face the most elastic residual demand curve in the United States, with a residual demand elasticity of 9.54, followed by France. Japan lies at the other end of the spectrum with a residual demand elasticity of only $2.94 .^{24}$ Column 4 of Table 1 reports the mean prices (unit values) for each destination, expressed in the exporter's currency. Everything else being

21 This specification gives the best fit and acceptable Durbin-Watson statistics.

22 The pass-through calculations are evaluated at the sample means of the exchange rates vis-a-vis each destination.

${ }^{23}$ As noted earlier, this interpretation is contingent on the assumption that market demand elasticities are similar across destinations, but that elasticities of alternative supply may differ.

${ }^{24}$ Although the parameters of the quantity and pricing equations have reasonable precision, the standard errors of the residual demand elasticities are too large to reject the null hypothesis of identical elasticities across destinations. This is perhaps not surprising given we have only 13 observations per destination market and the data are quite noisy. Reasonable anecdotal or other support may serve as an imperfect substitute for statistically significant differences across markets. Another possibility is to increase sample size. Unfortunately, German exports go from a seven digit classification system to 10-digit in 1988, which complicates the task. Moving from annual to quarterly frequency would increase the number of observations and we hope to explore this possibility in the future. 
equal, we would expect the markets with the highest elasticities to be associated with the lowest prices. A comparison between columns 3 and 4, however, contradicts this expectation. The most striking case is the one of the United States, which exhibits the highest average export prices, despite the high residual demand elasticity estimate for that market. There are two possible explanations for the finding of higher export prices in the more "competitive" markets. The first one would attribute price differences across markets to quality differences in the products sold in different destinations. Yet it seems unlikely that German beer exported to the United States is of markedly higher quality than German beer exports to Canada or France. The second explanation would link the price differentials to differences in the degree of collusion that German exporters can sustain in different markets. In particular, columns 3 and 4 in Table 1 suggest that exporters' behavior is more collusive the U.S. market. In general, elasticity-price comparisons seem to suggest that behavior is most collusive in the markets with the highest elasticities, as if exporters were trying to counterbalance tougher "outside" competition, with less intense "inside" competition.

To obtain an idea about the sources of different behavior across markets as well as the plausibility of our estimates, we assembled information on the number of competitors and their market shares in each market. Information is readily available for the United States, but harder to obtain for the other destination markets. ${ }^{25}$

For the United States, the hypothesis of a quite elastic demand curve facing German exporters seems plausible. Though imports experienced rapid growth during the early 1980s (see Figure 2), they still account for a quite small percentage of total sales (2-4\% during our sample period); in addition, the domestic market is highly concentrated with the top 6 brewers (Anheuser-Busch, Miller, Schlitz, Pabst, Coors and Heileman) capturing approximately $80 \%$ of the total domestic sales. Though market shares are poor indicators

25 The main sources of information for the U.S. are the annual "Modern Brewery Age Blue Book" and "Beer Marketer's Insights". 
of market power, the very low import shares in the U.S. make it unlikely, that importers can exercise market power in that market. On the other hand, product differentiation may work to their advantage; as Figure 3 indicates, imports are perceived as a distinct market segment in the U.S. beer industry. Low cross price elasticities between imports and domestic beer would make the residual demand curve facing importers steeper. Within the import category (see Figure 1), however, German producers come only third after the Netherlands (Heineken, Amstel) and Canada (Molson, Moosehead). Thus, in addition to facing competition from the domestic firms, German brewers also face competition from other importing countries, whose products are considered closer substitutes to German beer. As a result, one would expect the residual demand curve facing German exporters to be quite flat.

Does this intense competition create incentives to collude? While our approach cannot provide a definitive answer to this question, an examination of the market shares of German brands reveals that the market for German beer is highly concentrated; though there are approximately 40 German brands sold in the U.S., approximately $85 \%$ of the total German sales are accounted for by only two brands, Beck's and St. Pauli Girl. Thus the hypothesis of German exporters colluding in the U.S. does not seem a priori implausible. As mentioned earlier, detailed information on the other destination markets is more difficult to obtain as local trade journals for each destination country are not typically available in the United States. Yet a general idea about the competitive environment in each destination can be gleaned from the annual U.N. Commodity Trade Statistics which list imports for each destination country by major exporting country. Table 2 reports the import market shares by major exporting country for 1980 and 1985 in each of our destination markets.

Table 2 reveals that the market shares of the major exporters are relatively stable in the import markets during our sample period. The four destinations in our sample share some features with the U.S. beer market: (1) imports account for a small, but growing, share of total consumption and (2) the share of German exporters tends to be small, 
ranging from 2.5\% in Canada in 1985 to $28 \%$ in the United Kingdom in that same year. A closer look at the data reveals, however, that the set of competitors faced by German firms varies substantially across the markets. In Japan, for example, the main competitors are the United States and Singapore. Although German market share is small (about 10\% of the import market), product differentiation may work to their advantage since there is no major competition from other European brewers. The lack of a large number of outside competitors could explain the lower demand elasticity faced by the German firms in Japan, as compared to the United States where German firms hold a similar market share but face stiff competition from Heineken. At the other extreme is France, a destination in which German firms have a larger share of the market, but face competition from other European producers. In France, the residual demand was found to be more elastic. This appears to be true in general. The greater the presence of other European producers, the more elastic the residual demand faced by the German exporters, independent of the market share they happen to hold.

\section{2. U.S. Exports of Kraft Linerboard Paper.}

Kraft linerboard is a segment of the paper market in which the U.S. is a world leader, with over well over $\$ 1$ billion of exports annually, accounting for $50 \%$ of world exports of the product as of the mid 1980s. ${ }^{26}$ Exports typically account for $13-15 \%$ of U.S. production. The other major exporter of linerboard is Sweden, which accounted for about $30 \%$ of world exports during the 1980s. U.S. firms are the leading exporters to Asian and North American markets, but have lower market shares than the Swedish firms in European markets. This may be a misleading indicator of market power, however, since there is much more locally-produced supply in Japan than in Europe. Annual production in Japan comes relatively close to matching annual consumption in most years. Germany,

\footnotetext{
${ }^{26} \mathrm{Kraft}$ linerboard is a thin brown paper sheet made using a sulfite process that is then affixed to both sides of corrugated paper to form a cardboard box.
} 
Italy, and the United Kingdom, on the other hand, produce virtually no kraft linerboard although close substitutes (other types of linerboard) are produced locally.

Market shares in Europe changed dramatically in the early 1980s when the dollar soared and the Kroner tumbled against the DM. U.S. exports exceeded Swedish exports to Germany and the United Kingdom by about $60 \%$ as of 1980 . By 1985, however, Sweden was the leading exporter in both markets. Tappi Journal, an industry trade journal, cites evidence of the segmentation of national markets for linerboard: "The difference in the two markets can be illustrated by the $8 \%$ higher dollar price realized by U.S. producers on linerboard exports to Japan compared with those to Europe during 1984's first half."27 Our empirical work will confirm the divergence of export prices across markets and evaluate the intensity of competition in European relative to Asian markets.

Trade restrictions appear to be of limited importance in the linerboard market. Tariffs are generally low and have fallen slightly over the years. Canada imposed a $15 \%$ tariff as of 1974 which gradually fell to $9 \%$ by 1986 . The European Community levied an $11 \%$ tariff in 1974 which fell to $8 \%$ by 1986 . Japan's tariff rate on linerboard actually rose slightly, from $10 \%$ in 1974 to $15 \%$ by 1990 , although we were unable to determine the exact time of the increase (detailed tariff data for Japan were only available for 1974, 1979, and 1990 at the ITC Library in Washington). Sweden's tariff rate on linerboard was under 3\% during the entire sample period. Although we do not include tariff rates as a demand shifter due to missing observations, we are comforted by the fact that relative tariff rates remain quite stable over the sample. Thus, they are unlikely candidates to explain any of the variation in prices and quantities over time that is used to identify residual demand elasticities.

The pricing regressions for U.S. exports of kraft linerboard paper are presented in Table 3. The left-hand side variable is the dollar export unit value. We pool the

${ }^{27}$ Lynn's article "A Global Perspective of the Pulp and Paper Industry" was the source for much information on the industry. 
observations across destinations in a panel regression and experiment with a variety of cost and demand shifters as independent variables. In each case we include a constant term, the nominal exchange rate (an index of destination market currency per dollar), and the destination-market price level. In various specifications we add time trends, a full set of time effects, destination market real income, and source country real output (the state of the domestic market may influence international markets).

We are interested in the coefficient on the nominal exchange rate, which is interpreted as the "pricing-to-market" (PTM) coefficient: It gives us the degree to which exchange rate induced price changes in foreign markets are offset by markup adjustment. For example, a coefficient of -0.5 means that a $10 \%$ depreciation of the destination market currency is matched by a $5 \%$ reduction in the markup over cost, which implies a $5 \%$ increase in the foreign currency price of the product. Thus, $50 \%$ of the price increase that would have occurred in the foreign market due to the exchange rate change is offset by PTM. A coefficient of 0 means that markups are invariant to exchange rate changes which are fully passed through to local currency prices, while a coefficient of -1 implies markup adjustment offsets the exchange rate change completely leading complete stabilization of local currency prices. In calculating the residual demand elasticities, we will be interested in the response of the local currency price to the exchange rate change, which equals 1 plus the PTM coefficient.

Table 3 reports the exchange rate coefficient, the R-squared, and the DurbinWatson statistic for each destination for each of seven different specifications. In each case, all equations are estimated simultaneously using OLS under the assumption of uncorrelated errors. Three specifications include a full set of time effects, in which case estimation of an unrestricted covariance matrix of residuals is not possible. In general, the equations with the time effects fit much better. There is evidence of positive autocorrelation in some of the equations, but it does not appear to be a serious problem. 
The coefficients of interest tend to be quite stable across specifications for each destination except Canada, although there is one serious sign reversal in the Japanese equation which includes the minimal set of demand and cost shifters. We will focus mainly on the specifications which include time effects, since that is the most extensive set of controls for confounding factors. In those specifications, the PTM coefficients are statistically significant, or nearly so, for all destinations except Canada and Australia. The coefficients confirm a high degree of PTM in the market for kraft linerboard paper. Local currency price stabilizing markup adjustment is greatest in Japan, Germany, and Italy, and less apparent in the United Kingdom, Australia, and Canada.

Table 4 reports the results of the analogous quantity equations. The same specifications and estimation procedures are used for quantities as were used in the pricing equations. For the equations with time effects included, the Durbin-Watson statistics show remarkably little evidence of positive autocorrelation. Lagged adjustment does not appear to be evident in the annual data for this market. The response of quantities to exchange rate shocks is much less precisely estimated than the response of prices, although the coefficients are statistically significant when time effects are included for Germany, the United Kingdom, Japan, and Canada in some cases. The Canadian coefficient changes sign when U.S. output is removed from the equation, which may be due to a high correlation between U.S. and Canadian output levels. The parameter estimates for Germany, the United Kingdom, and Japan are again in a fairly narrow range across specifications, which gives us more confidence in these results.

The implied residual demand elasticities are in Table 5. Recall that we expect the residual demand elasticities to be negative (quantity falls as the local currency price rises), and that a more competitive market would have more actual or potential suppliers, which would imply a larger negative value of this elasticity. If we turn first to the equations that use time effects, we see that the most competitive destination in these terms is the Japanese market, followed by Germany. The United Kingdom, Italy, and Canada look somewhat 
less competitive, with the choice of specification being quite important in the Canadian case due to the switch in sign between the specifications with and without U.S. domestic output. Australia looks least competitive in most specifications. The equations for Germany and Italy seem quite sensitive to whether time effects are included in the model. They look markedly less competitive for some specifications that exclude the fixed effects. There are strong reasons to prefer the model with time effects as a cost shift control, so we are not so concerned with these specifications.

Although the price and quantity coefficients in Tables 3 and 4 are often statistically significant, few of the implied residual demand elasticities are significantly different from zero and probably none of them are different from each other. Recall that the elasticities are constructed as a ratio of the quantity coefficient and (one plus) the price coefficient. As the denominator goes to zero, the elasticity approaches infinity then abruptly changes sign as the denominator crosses zero and becomes negative. Consequently, large elasticities that are a result of a high degree of pricing to market (so that $1+\beta$ is near 0 ), will have commensurately larger standard errors. In linerboard, Japan and Germany have higher implied elasticities mainly because of higher estimated degrees of PTM. The higher degree of PTM increases the probability of the denominator being in the neighborhood around zero, and translates into larger standard errors for these destinations. ${ }^{28}$

The conclusions about the intensity of outside competition seem to fit well with data on exports and domestic production among OECD countries. As noted in Table 6 which presents facts on our six linerboard destinations, Japan and Canada have the largest sources of locally-produced supply, so the finding that exports to the Japanese market face substantial outside competition is appealing. For the Canadian case, we suspect that the relatively lower variation in exchange rates has made it difficult to estimate the parameters well. In Europe, Germany is the only market with a large domestic supply of linerboard

\footnotetext{
28 We are presently exploring alternative ways to estimate these elasticities which will hopefully mitigate this problem.
} 
(although it is not kraft linerboard) and it appears to be more competitive than other European markets. Italy has no domestic production of any linerboard and is not very near alternative sources of supply. In general, we find that the method yields results that fit roughly with the facts we have been able to assemble about this industry.

\section{Concluding Remarks}

The objective of this paper has been to measure outside and inside competition in export destination markets for German beer and U.S. linerboard by extending the multiplemarket pricing framework to an investigation of quantities as well. The key variable that identifies the parameters we use to construct measures of the intensity of outside competition and the nature of conduct is the exchange rate between the exporter and the destination markets, which rotates the exporters' supply schedule.

In the case of German beer, we find weak evidence that the United States appears to have the most elastic residual demand schedule, although one cannot reject the hypothesis that each destination has the same residual demand elasticity. Nonetheless, price on German beer exports to the United States are relatively high, which suggests that German firms are able to coordinate their sales activities in the U.S. market better than elsewhere, thus enabling them to capture more of the potential surplus implied by the downward sloping residual demand schedule.

For U.S. linerboard, we find that Japan has the highest estimated residual demand elasticity, reflecting a greater intensity of outside competition. This finding is quite robust across alternative specifications, although as noted, residual demand elasticities are not significantly different across specifications. It also appears to be consistent with the available evidence on the market shares of U.S. firms in different export destinations. Japanese producers' total output tends to be nearly $95 \%$ of total domestic consumption, which means U.S. exporters face competition from a local supply capable of satisfying 
nearly the entire market. This situation should lead to a relatively flat alternative supply schedule and thus a flat residual demand schedule, meaning that market shares can be quite sensitive to relative prices. Australia, which is an isolated market with no locally-produced supply of linerboard has an extremely low residual demand elasticity, which seems to confirm the absence of any outside competition for the U.S. exporters. 


\section{REFERENCES}

Aw, Bee Yan, "An Empirical Model of Markups in a Quality-Differentiated Export Market," Journal of International Economics, 1992.

Aw, Bee Yan, "Price Discrimination and Markups in Export Markets," Journal of Development Economics, 1993.

Bresnahan, Timothy, "Empirical Studies of Industries with Market Power," Handbook of Industrial Organization, R. Schmalensee and R. Willig, editors, 1989.

Dombusch, Rudiger, "Exchange Rates and Prices", American Economic Review, March 1987, 77, 93-106.

Feenstra, Robert, "Symmetric Pass-Through of Tariffs and Exchange Rates Under Imperfect Competition: An Empirical Test", Journal of International Economics, February 1989, 27, 25-45.

Feenstra, Robert, Gagnon, Joseph, and Knetter, Michael, "Market Share and Exchange Rate Pass-Through in World Automobile Trade," National Bureau of Economic Research, Working Paper \#4399, July 1993.

Feinberg, Robert, "The Interaction of Market Power and Exchange Rate Effects on German Domestic Prices," Journal of Industrial Economics, September 1986, 61-70.

Froot, Kenneth, and Klemperer, Paul, "Exchange Rate Pass-Through When Market Share Matters", American Economic Review, September 1989, 79, 637-654.

Gagnon, Joseph, and Knetter, Michael, "Markup Adjustment and Exchange Rate Fluctuations: Evidence from Panel Data on Automobiles", forthcoming in Journal of International Money and Finance, 1995.

Giovannini, Alberto, "Exchange Rates and Traded Goods Prices", Journal of International Economics, February 1988, 24, 45-68.

Goldberg, Pinelopi K., "Product Differentiation and Oligopoly in International Markets: The Case of the U.S. Automobile Industry," forthcoming in Econometrica, 1995. 
Hall, Robert E., "The Relation Between Price and Marginal Cost in U.S. Industry," Journal of Political Economy, Vol. 96, October 1988, 921-47.

Harrison, Ann, "Imperfect Explanations for Imperfect Pass-Through: Market Power and Exchange Rates in the U.S. Steel Industry," manuscript 1993.

Hooper, Peter, and Mann, Catherine, "Exchange Rate Pass-Through in the 1980s: The Case of U.S. Imports of Manufactures", Brookings Papers on Economics Activity:1, 1989.

Isard, Peter, "How Far Can We Push the Law of One Price?", American Economic Review, 1977, 942-48.

Kasa, Kenneth, "Adjustment Costs and Pricing-to-Market: Theory and Evidence”, Journal of International Economics, February 1992, 1-27.

Knetter, Michael, "Price Discrimination by U.S. and German Exporters", American Economic Review, March 1989, 79, 198-210.

Knetter, Michael, "International Comparisons of Pricing-to-Market Behavior", American Economic Review, June 1993, 83, 473-486.

Knetter, Michael, "Pricing to Market in Response to Unobservable and Observable Shocks", International Economic Journal, forthcoming 1995.

Kravis, Irving and Lipsey, Robert, "Export Prices and the Transmission of Inflation", American Economic Review, February 1977, 155-63.

Krugman, Paul, "Pricing to Market When the Exchange Rate Changes", Arndt and Richardson, eds., Real-Financial Linkages in Open Economies, MIT Press, 1987.

Lawrence, Robert, "Japan's Different Trade Regime: An Analysis with Particular

Reference to Keiretsu," Journal of Economic Perspectives, Summer 1993, 3-20.

Lawrence, Robert, and Rangan, Subramanian, "The Response of U.S. Firms to Exchange Rate Fluctuations: Piercing the Corporate Veil," forthcoming in Brookings Papers on Economic Activity. 
Lee, Jaewoo, "Exchange Rate Pass-Through and Concentration in a Small Economy: The Evidence from Korea," UC Irvine, unpublished manuscript, November 1993.

Levinsohn, James, "Testing the Imports as Market Discipline Hypothesis," Journal of International Economics, 1993.

Marston, Richard, "Pricing to Market in Japanese Manufacturing", Journal of Intermational Economics, December 1990, 29, 217-36.

Richardson, J.David, "Commodity Arbitrage and the Law of One Price”, Journal of International Economics, 1978.

Saxonhouse, Gary, "What Does Japanese Trade Structure Tell Us about Japanese Trade Policy?," Joumal of Economic Perspectives, Summer 1993, 21-44.

Stigler, G. and J. Kindahl, The Behavior of Industrial Prices, NBER, New York 1970. Yang, Jiawen, "Exchange Rate Pass-Through in the U.S. Market: A Cross-Country, Cross-Product Investigation," Vanderbilt University manuscript, December 1993. 
Table 1. German Exports of Beer

Results from reduced-form price and quantity regressions

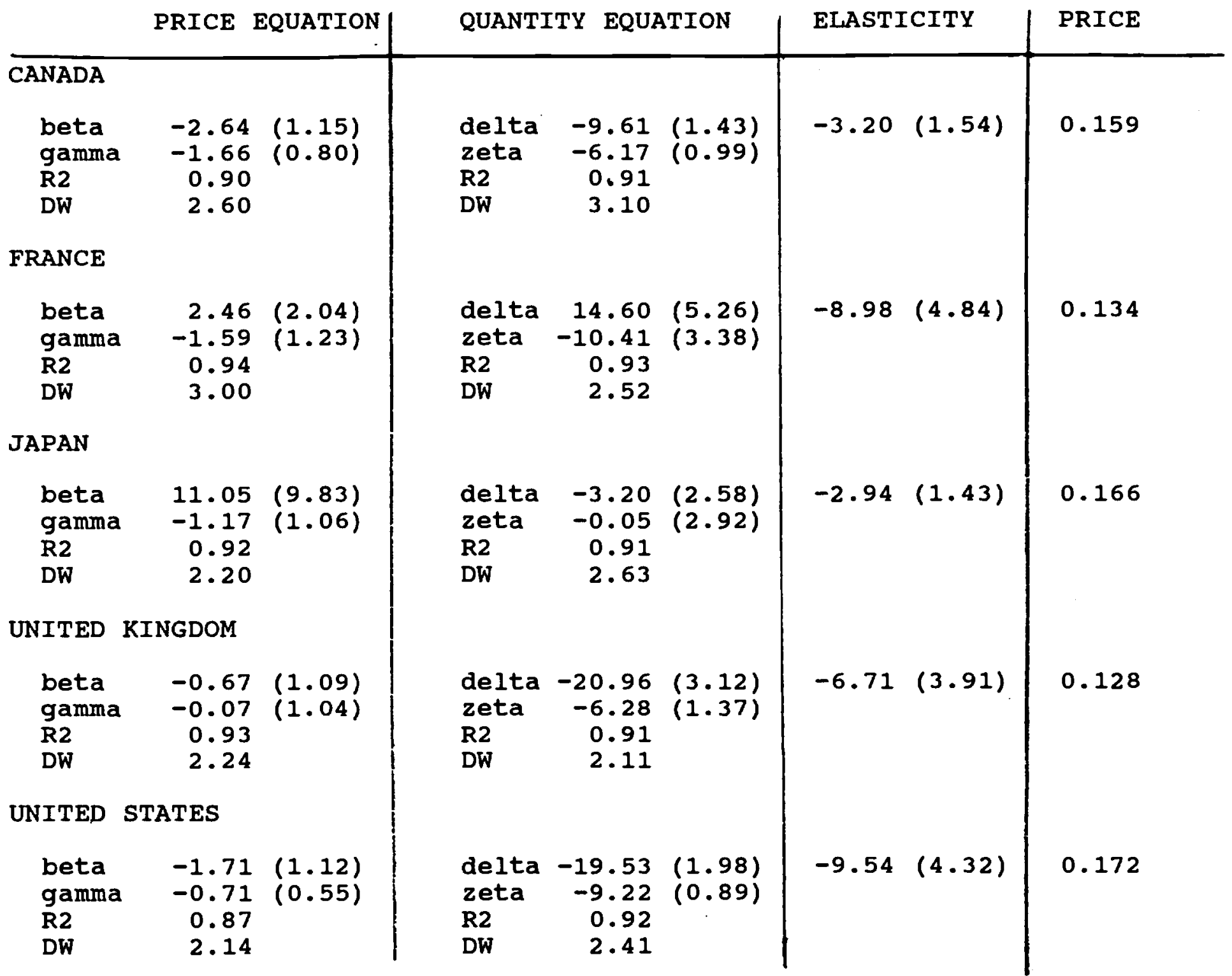

Notes: Standard errors in parantheses.

The reported elasticities were evaluated at the sample means of exchange rates. The reported standard errors for the elasticity estimates were computed using the delta method; that is, it was assumed that the distribution was approximately normal, and that the elasticity variance is equal to cVc', where $V$ is the covariance matrix of the relevant parameters and $c$ is the row vector of the partial derivatives of the elasticity with respect to these parameters. 
Table 2: Share of Beer Import Market

By Destination and Major Exporting Country

1980

\begin{tabular}{|c|c|c|}
\hline & 1980 & \\
\hline \multirow[t]{2}{*}{ Destination: } & Canada & \\
\hline & $\begin{array}{l}\text { U.S.A. } \\
\text { Netherlands } \\
\text { Germany }\end{array}$ & $\begin{array}{r}78 \% \\
12 \% \\
4 \%\end{array}$ \\
\hline \multirow[t]{2}{*}{ Destination: } & France & \\
\hline & $\begin{array}{l}\text { Belgium/Lux. } \\
\text { Netherlands } \\
\text { Germany }\end{array}$ & $\begin{array}{l}65 \% \\
16 \% \\
14 \%\end{array}$ \\
\hline
\end{tabular}

Destination: Japan
U.S.A.

Netherl.

Germany
$80 \%$

$12 \%$

$2.5 \%$

Belg./Lux. $67 \%$

Germany

$14 \%$

Netherlands

$9 \%$

U.S.A.

Germany

France

$48 \%$

$11 \%$

$10 \%$

Destination: United Kingdom

Ireland

Germany

$65 \%$

Netherlands
Ireland Germany Netherlands
$47 \%$

$28 \%$

$9 \%$ 


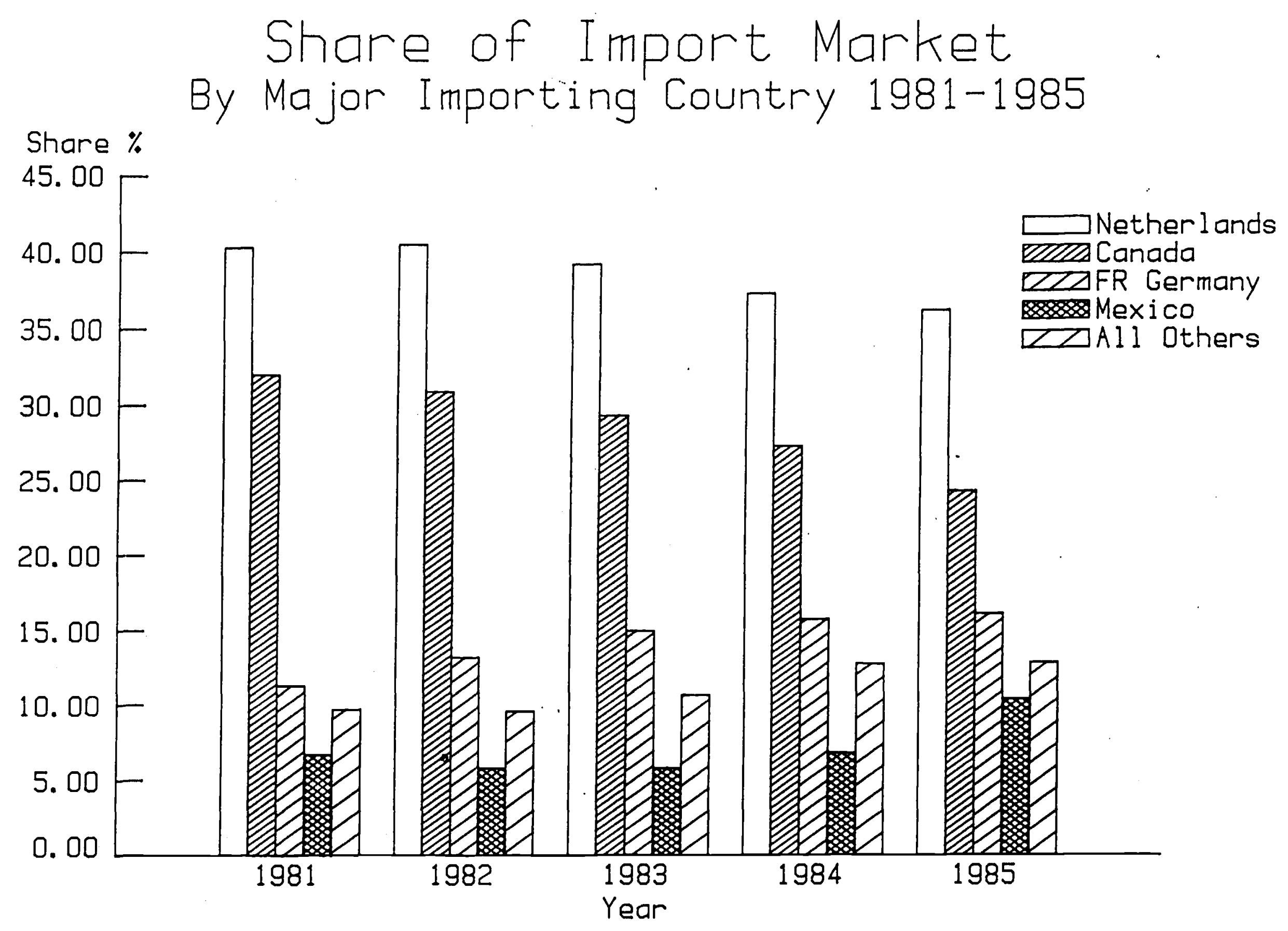


Figure 2: U.S. Beer Market

\section{Import Growth vs Domestic Growth. 1980-1985}

$\%$ Change

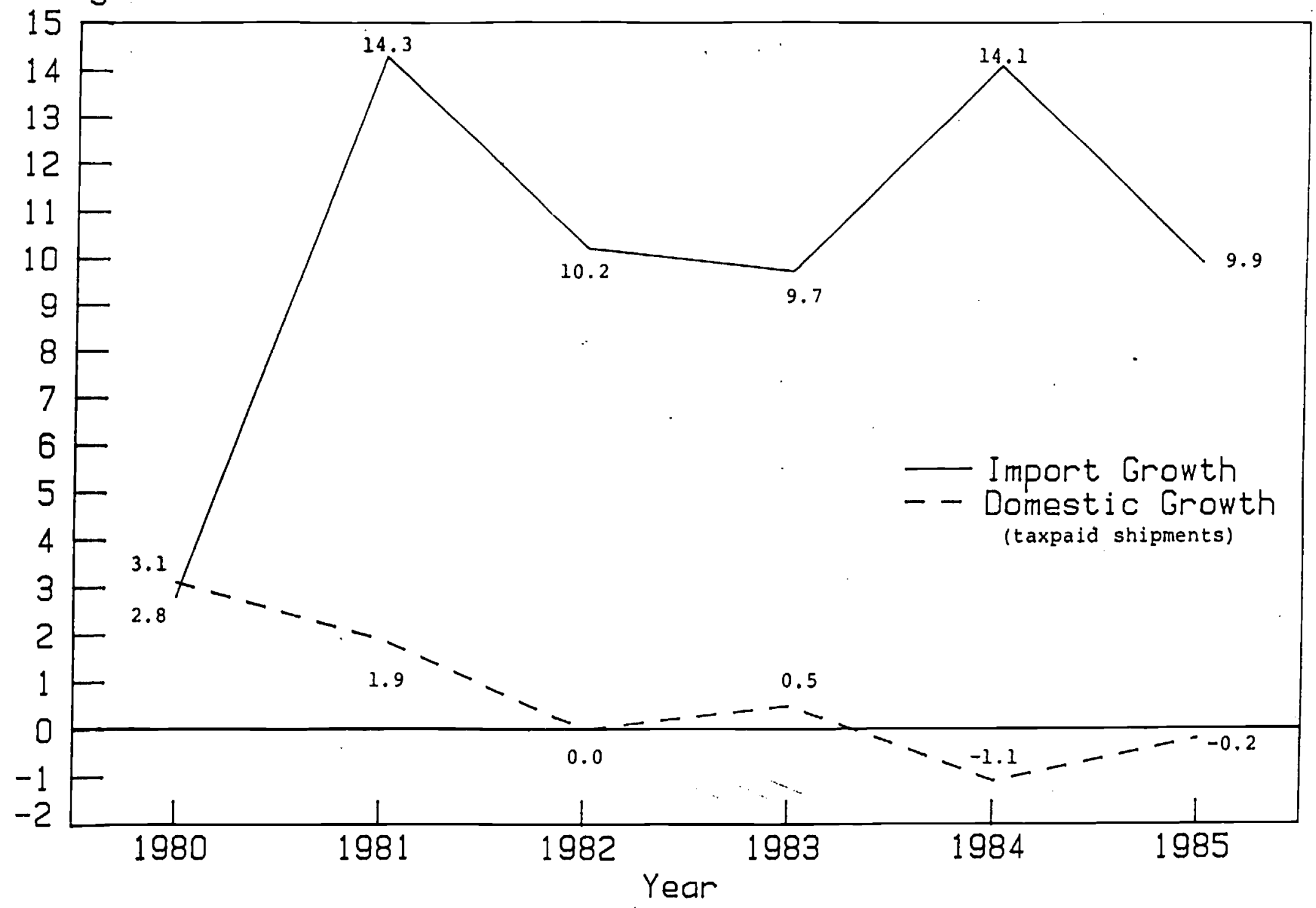


Figure 3: U.S. Beer Market

\section{Share of US Consumption 1980, 1982, 1985}
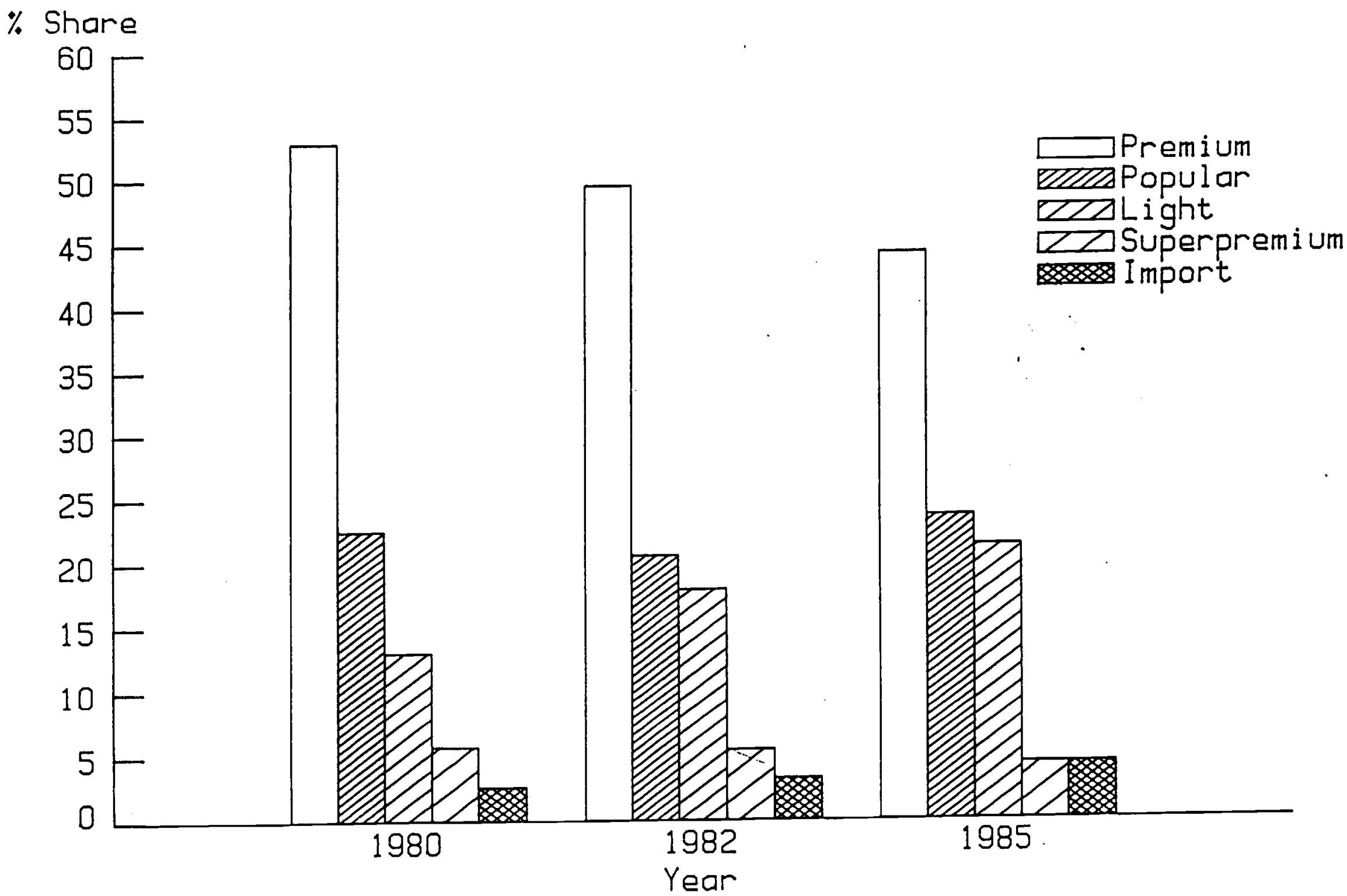
Table 3. U.S. Exports of Kraft Linerboard Paper.

Results for reduced-form export price regressions

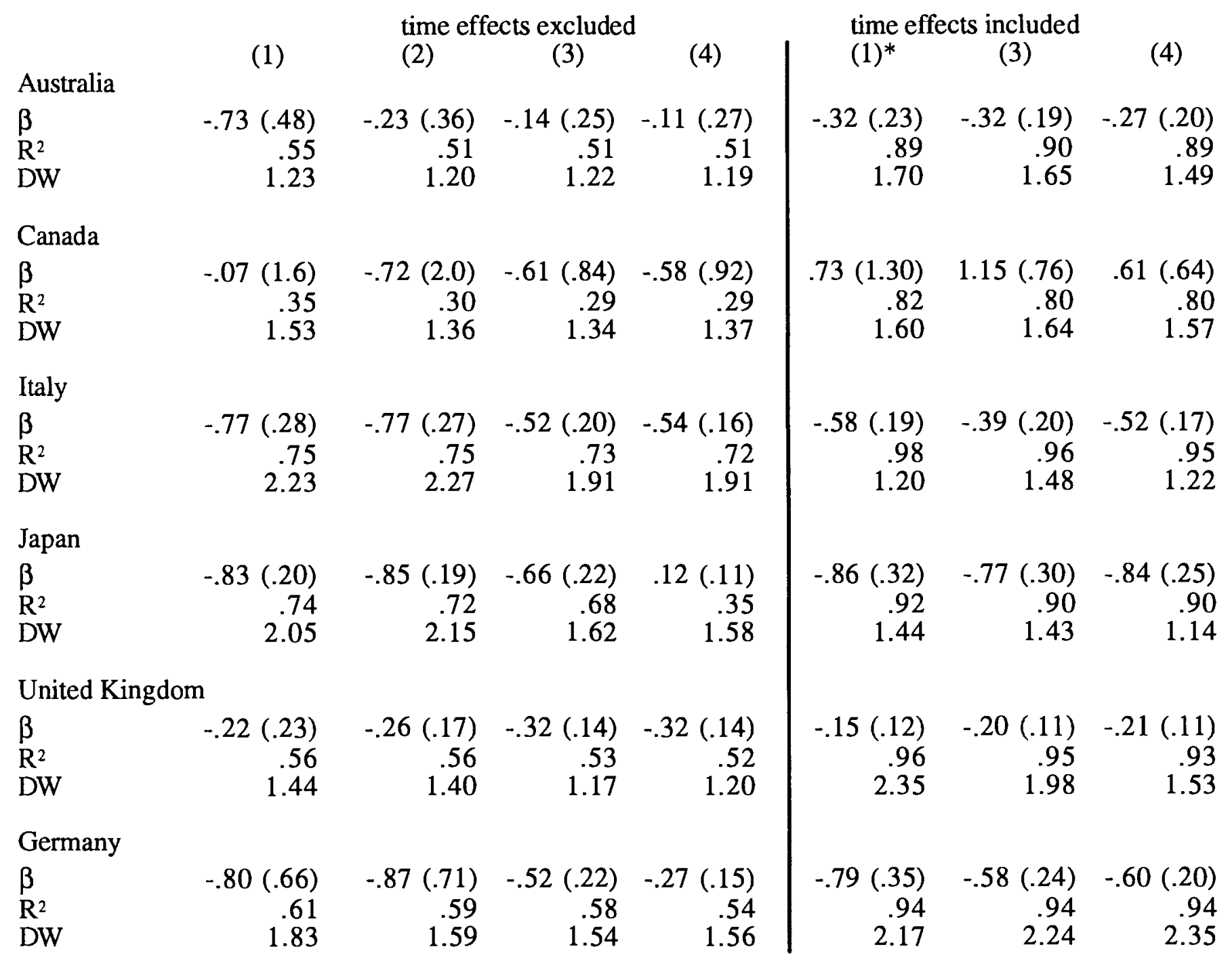

Note: Standard errors in parentheses.

Demand and cost shifters in addition to the nominal exchange rate included in each specification are as follows:

(1) constant, time trend, destination real income, destination price level, real domestic output

(2) same as (1) with time trend removed

(3) same as (2) with real domestic output removed

(4) same as (3) with destination income removed

* time trend is not included in the model with full set of time effects 
Table 4. U.S. Exports of Kraft Linerboard Paper.

Results for reduced-form export quantity regressions
(1) $\quad$ time effects excluded
time effects excluded
time effects excluded

(4)

time effects included

$(1)^{*}$

(3)

(4)

Australia

$\delta$

$\mathrm{R}^{2}$

DW

$-.02(1.4)$

$-.27(.85)$

.90

$.31(.66)$

$-.40(.89)$

.90

.90

$.24(.91)$

$.84(.85)$

$.11(.85)$

2.07

.96
2.60

.92

1.77

2.62

2.00

Canada

$\delta$

$\mathrm{R}^{2}$

$.60(1.8)$

$-.99(2.3)$
.37

$\begin{array}{rr}-4.0(1.8) & -3.86(1.9) \\ .32 & .31 \\ 2.27 & 2.19\end{array}$

$3.2(4.2)$

$\begin{array}{rr}-4.9(1.8) & -4.5(3.0) \\ .07 & .04 \\ 1.94 & 1.38\end{array}$

Italy

$\delta$

$\mathrm{R}^{2}$

$2.38(.92)$

2.69

2.31

.18

1.80

DW .43

2.33 (.94)

$1.26(86)$

$-.08(.66)$

.32

.04

$-.53(1.0)$

$.07(1$

$(1.1)$
.77

$-.91(.98)$

.41
1.79

1.13

.84

2.25

.55

Japan

$\delta$

$\mathrm{R}^{2}$

$$
\begin{array}{r}
-1.26(.56) \\
.94 \\
1.91
\end{array}
$$

$-1.54(.85)$

.85) $-1.11(.81)$

$-2.78(.60)$

$-2.44$

$(1.2)$
.9

.96

.85

$.60)$
.81
.86

1.60

$-2.47(1.0)$

$1.0)$
.94

$-2.5(1.1)$

.89

1.59

.91

United Kingdom

\begin{tabular}{lrrrr|rrr}
$\delta$ & $-1.09(.34)$ & $-.61(.34)$ & $-.59(.32)$ & $-.59(.32)$ & $-.88(.49)$ & $-.84(.50)$ & $-.98(.41)$ \\
$\mathrm{R}^{2}$ &. .37 & .22 & .22 & .22 & .88 & .83 & .89 \\
DW & 1.57 & 1.09 & 1.09 & 1.09 & 2.00 & 2.02 & 2.04 \\
& & & & & & & \\
West Germany & & & & & & & \\
$\delta$ & $1.76(.65)$ & $1.78(.66)$ & $-1.32(.77)$ & $-.74(.51)$ & $-2.09(1.0)$ & $-2.31(.91)$ & $-1.27(.85)$ \\
$\mathrm{R}^{2}$ &. .78 & .78 & .62 & .57 & .82 & .81 & .71 \\
DW & 2.30 & 2.32 & 2.11 & 1.80 & 2.24 & 2.28 & 1.78
\end{tabular}

Note: Standard errors in parentheses.

Demand and cost shifters in addition to the nominal exchange rate included in each specification are as follows:

(1) constant, time trend, destination real income, destination price level, real domestic output

(2) same as (1) with time trend removed

(3) same as (2) with real domestic output removed

(4) same as (3) with destination income removed

* time trend is not included in the model with full set of time effects 
Table 5. U.S. Exports of Kraft Linerboard Paper.

Implied Residual Demand Elasticities from Estimates in Tables 3 and 4.

time effects excluded from the model

(1)

(2)

$-0.35$

(1.11)

(5.39)

0.65

(2.25)

$-3.53$

(26.3)

(3)

\begin{abstract}
0.36
\end{abstract}
$(0.78)$

Canada

Italy

$$
10.40
$$

(13.2)

10.19

(12.7)

$-10.35$

(22.7)

2.63
$(2.11)$

$-10.05$

(13.6)

$-3.29$

(3.24)

(8.88)

United

Kingdom

$$
\begin{aligned}
& -1.40 \\
& (0.60)
\end{aligned}
$$

$-0.82$

$(0.49)$

$-0.86$

$(0.51)$

13.34
$(71.0)$

-2.77
$(2.05)$

(20.1)

West Germany $\begin{array}{r}8.69 \\ (28.5)\end{array}$
(4)

-0.45
$(1.01)$

$-9.08$

$-0.18$

(1.42)

$-2.49$

(0.59)
$-17.70$
(41.9)

$-0.36$

(1.36)

(1)

time effects included
$-0.87$

$(0.51)$

$-1.02$

(0.73)
1.86

(2.82)

$-1.26$

(2.55)

(1.76)

$-10.60$

(14.5)

$-2.27$

(1.17)

0.12$$
(14.5)
$$$$
\begin{aligned}
& -1.05 \\
& (0.64)
\end{aligned}
$$$$
\begin{aligned}
& -1.04 \\
& (0.59)
\end{aligned}
$$

-5.56
$(3.84)$

(16.7)
(4)

0.16 (1.17)

$-2.83$

(2.16)

$-1.88$

(2.13)

$-15.80$

(25.4)

$(0.55)$

$-3.25$

(2.74)

Note: A higher degree of outside competition is implied by larger negative values of the residual demand elasticities. 
Table 6. The Kraft Linerboard Market in 1987

Destination

Australia

Canada

United Kingdom

Germany

Italy

Japan
18.4

651.3

651.4

608.1

415.0

2284.0

Market Shares by Source Country
Domestic Firms US Exporters Swedis

tion 1 Domestic Firms US

0.00

0.93

0.03

0.95

0.95

0.05

0.00

1.00

0.00

0.30

0.38

0.30

0.00

0.17

0.34

0.17

0.13

0.21

0.13

0.25

0.92

0.06

0.00

0.74

1 Consumption is measured in '000 tons of product. 